Volume 9, No.5, September - October 2020

International Journal of Advanced Trends in Computer Science and Engineering

Available Online at http://www.warse.org/IJATCSE/static/pdf/file/ijatcse154952020.pdf

https://doi.org/10.30534/ijatcse/2020/154952020

\title{
Analysis of web platforms of learning management systems for distance education in the face of social isolation
}

\author{
Alexi Delgado ${ }^{1}$, Enrique Lee Huamaní ${ }^{2}$, Hugo Obispo-Mego ${ }^{3}$, Daniel Justo-López ${ }^{4}$ \\ ${ }^{1}$ Mining Engineering Section, Pontificia Universidad Católica del Perú, Lima-Perú, kdelgadov@ pucp.edu \\ ${ }^{2}$ Image Processing Research Laboratory, Universidad de Ciencias y Humanidades, Lima-Perú, ehuamaniu@uch.edu.pe \\ ${ }^{3}$ Systems Engineering Program, Universidad de Ciencias y Humanidades, Lima-Perú, hugobispom @uch.pe \\ ${ }^{4}$ Systems Engineering Program, Universidad de Ciencias y Humanidades, Lima-Perú, danjustol@uch.pe
}

\begin{abstract}
Education is one of the sectors that were affected by the Covid-19 pandemic that forced citizens to keep us isolated in our homes, however, education had to adapt to circumstances and as a result Online Classes were implemented. in the different educational centers for which it is necessary to know the best online learning system to be able to implement in the institutions. In this work, a work methodology based on Analytic Hierarchy Process (AHP) was applied to be able to compare the different LMS shown in this article. In this case study, three different LMS platforms were evaluated. The results of this study indicated that the best LMS platform to implement in schools was Moodle. Based on these results, educational institutions could apply this LMS to their online teaching modality since it offers better characteristics compared to Chamilo and Google Classroom.
\end{abstract}

Key words: AHP, LMS, Online Classes.

\section{INTRODUCTION}

Distance education is an important field in which teachers and students are part of cognitive learning. Today, in the face of this social isolation, we can see that there are several schools and institutes that do not have a web platform for the LMS learning management system, which analyzed the different platforms available below[1].

There are many methodologies that help optimize the problem for each investigation. In this scientific article, the LMS will be discussed using the AHP methodology, since it is used for the administration, distribution and control of activities in the online learning of an institution or organization, achieving asynchronous work among the participants [2].

For this reason, we want to analyze the different web platforms for online learning management, due to the crisis that our country is going through, but the variety of tools that exist makes it difficult to choose just one. Each tool has particularities that make adaptation flexible according to what the company or organization requires [3].
Within this scientific article, we will detail three learning management system web platforms and discuss the AHP methodology. These tools are aimed at consolidating academic processes and have been expanded to the point of being the best known on the market [4].

This work is structured as follows, in the next section number II the methodology used for the analysis of E-learning platforms will be described in detail. In section III the results obtained will be evidenced and finally in section IV the own results will be discussed and the conclusions will be presented.

\section{METHODOLOGY}

This section will detail the steps that will be followed for the analysis of web platforms for the learning management system, for this we have the AHP methodology that was developed by Saaty. This method is successfully applied to different types of MCDM problems. Although popular, AHP is criticized for its inability to handle uncertain and imprecise evaluations of decision makers. To face uncertain judgments, comparisons of alternatives and criteria can be expressed as fuzzy sets or fuzzy numbers that incorporate the vagueness of human preferences. This fuzzy set can be provided by the most popular MCDM method which is Fuzzy (Analytical Hierarchy Process) [5].

E-Learning platforms have to comply with some rules to be effective and also some platforms can be really effective within a well defined scenario. This is a multi-criteria decision problem. Next, the steps to follow will be detailed [6].

\section{A. Definition of the elements.}

In this case, the first level is the selection of the best E-Learning platform for the selected scenario.

This step is made up of features that take into account the LMS, technological and usability aspects.

B. Sort the Items

The third step is to sort the items from the highest level 
to the lowest level that are generally in the element priority range.

\section{Compare the Elements}

The fourth step is to compare the set of elements automatically assigned in each comparison.

\section{Review and Improve}

Having made the comparisons, the consistency is determined using the eigenvalue, the elements must be reviewed and improved [7].

In this case, the usability function is of great importance, also the tools for adapting the learning path are important because the target group could be very heterogeneous. So according to the AHP approach we have to compare several platforms with each other for each characteristic and scenario as shown in Table 1 [7].

Table 1: Characteristics considered ordered by importance

\begin{tabular}{|c|c|c|}
\hline ECDL Course & Blended Course & $\begin{array}{c}\text { Professional } \\
\text { Trainning }\end{array}$ \\
\hline Management & Management & Usability \\
\hline $\begin{array}{l}\text { Management and } \\
\text { enjoyment of } \\
\text { interactive } \\
\text { learning objects }\end{array}$ & $\begin{array}{l}\text { Management and } \\
\text { enjoyment of } \\
\text { interactive } \\
\text { learning objects }\end{array}$ & $\begin{array}{l}\text { Adaptation of } \\
\text { learning path }\end{array}$ \\
\hline Usability & $\begin{array}{l}\text { Collaborate } \\
\text { Approach }\end{array}$ & $\begin{array}{l}\text { Management and } \\
\text { enjoyment of } \\
\text { interactive } \\
\text { learning objects }\end{array}$ \\
\hline $\begin{array}{l}\text { Adaptation of } \\
\text { learning path }\end{array}$ & Usability & Management \\
\hline $\begin{array}{l}\text { Collaborate } \\
\text { Approach }\end{array}$ & $\begin{array}{l}\text { Adaptation of } \\
\text { learning path }\end{array}$ & $\begin{array}{l}\text { Collaborate } \\
\text { Approach }\end{array}$ \\
\hline
\end{tabular}

\section{CASE STUDY}

In this section, an analysis will be made of 3 web platforms of the E-learning management system, which are Chamilo, Moodle and Classroom to know which one meets all the student's functionalities, which we will start by talking about LMS and we will detail them then.

A Learning Management System (LMS) is an online learning management system, which allows us to administer, monitor and evaluate the different activities designed and programmed within a virtual process (e-learning), or blended learning (Blended Learning).

LMS are used mostly by companies that want to train their employees as well as by educational organizations and schools. Currently there are many platforms, in this research 3 platforms will be explained in order to choose the one that suits the needs of the school for a diverse use which will also be used to train teachers online in this social isolation and in turn they can use this platform for a good academic performance.

This section is based on a general explanation of the platforms and a mention of technical characteristics for their implementation.

\subsection{Definition of the elements}

\section{A. CHAMILO}

It is an open source platform created in 2010 and developed with the aim of improving access to education and knowledge, allowing any user or company to create, study and modify courses, among other things. Chamilo is a less ambitious system where its purpose is e-learning and which is more pleasant and easier to learn to use and manage in turn, it is currently the 4th most popular Open source in the higher education sector[8]. His image of the platform is shown below in Figure 1.

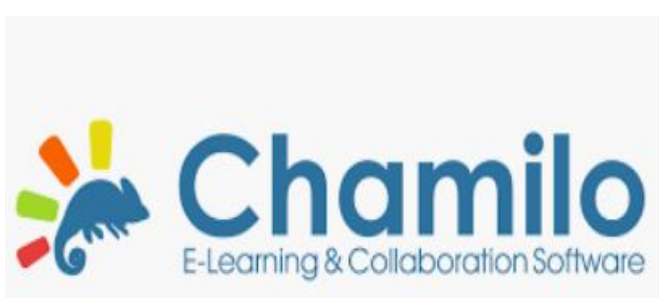

Figure 1: PlatformE-Learning Chamilo

\section{B. MOODLE}

It was created in 2002, it is a free platform focused on online teaching, it is a robust system that covers various aspects of e-learning that generally use it as a blog, social network and even as support for the educational system[9]. Next, Figure 2 shows its referential image.

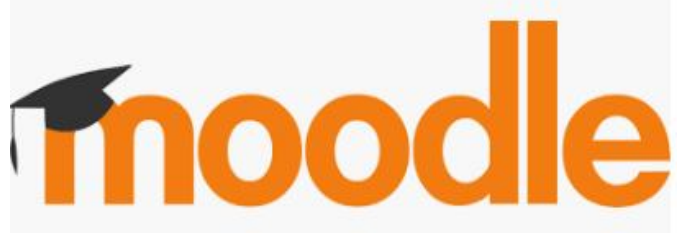

Figure 2: PlatformE-Learning Moodle

\section{GOOGLE CLASSROOM}

This platform was launched on August 12, 2014, it is an e-learning platform that works from the cloud, it is free and can be used by people who have Gmail accounts or non-profit organizations. It can be used in the web version, 
being compatible with the main browsers or through the mobile applications for Android and IOS.

Google worked with educators from all over the country to create this platform, being an agile tool (Google apps for education) that is easy for teachers to use, where they can create and organize assignments, provide comments and communicate quickly with students[10].

Classroom intertwines google docs, drive, and Gmail to help teachers create and collect paperless assignments, they can also see who completes the assignment and interacts in real time with students inside or outside of class, in Figure 3. Its referential image is displayed.

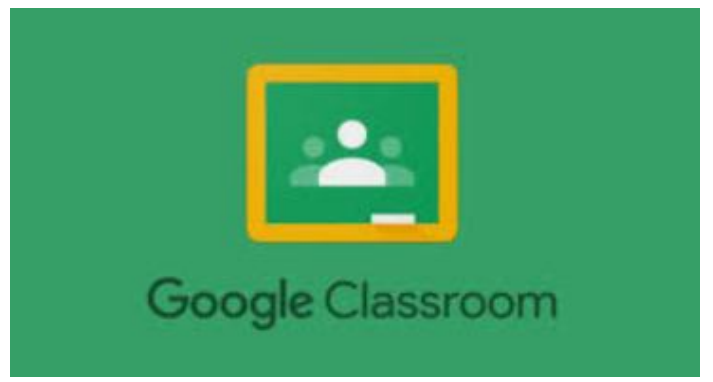

Figure 3: PlatformE-Learning Classroom

\subsection{Features}

\section{A. CHAMILO}

Regarding the operating system, Chamilo can remain in an ecosystem under Windows / Linux as long as the Apache server is properly implemented from version 2.2 onwards. The technological tools to be used in its implementation are the following with respect to Table 2.

Table 2: Technological tools

\begin{tabular}{|c|c|}
\hline Name & $\begin{array}{c}\text { Minimum version } \\
\text { required }\end{array}$ \\
\hline Apache & 2.2 \\
\hline MySQL o MariaDB & 5.1 y 5.0 \\
\hline PHP & 5.4 \\
\hline
\end{tabular}

\section{B. MOODLE}

Regarding the operating system, Moodle will depend on Windows / Linux, a web server and a database, while the apache server is implemented in its version 2.6.

The technological tools that must be used in its implementation are as follows in Table 3, which we will see below.
Table 3: Moodle requirements

\begin{tabular}{|c|c|}
\hline Name & $\begin{array}{c}\text { Minimum } \\
\text { version } \\
\text { required }\end{array}$ \\
\hline Apache o IIS & 2.6 \\
\hline $\begin{array}{c}\text { MySQL,MariaDB,PostgreSQL, } \\
\text { MSSQL u Oracle }\end{array}$ & $\begin{array}{c}5.31,5.3 .5,8.3, \\
9.0 \text { y } 10.2\end{array}$ \\
\hline PHP & 5.4 \\
\hline
\end{tabular}

\section{GOOGLE CLASSROOM}

Regarding Google Classroom, its characteristics at the time of its implementation is that you must have a Gmail and internet account to be able to access it and thus enjoy its benefits, in terms of its server, it works directly from the platform and does not need a specific version In order to be updated, among some novelties that the Classroom offers us are:

\section{- Google Docs}

- Drive

- Gmail

\subsection{Sort the Items}

Regarding the order of the elements, in this case the E-learning platforms have a rank of positioning worldwide, the selection of the best LMS is based on a bar graph, where we can visualize the position of each open source platform, such as shown in Figure 4.

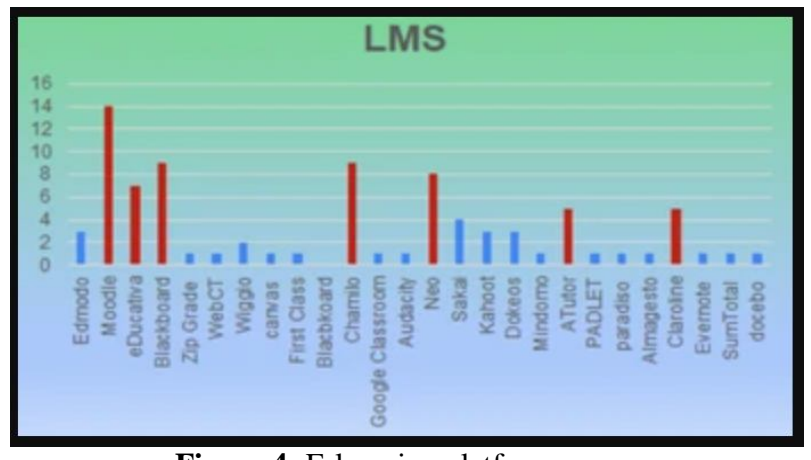

Figure 4: E-learning platform range

\subsection{Compare the Elements}

Lastly, we have the technical characteristics of the 3 platforms mentioned above, where they will be compared to each other to find out which is the most appropriate to use, mentioning the customization of the learning proposal, user support, student tools and learning promotion collaborative[11]. As Table 4 below shows. 
Table 4: LMS Technical Characteristics

\begin{tabular}{|c|c|c|c|c|c|}
\hline \multicolumn{2}{|c|}{ FEATURES / LMS } & Moodle & Chamilo & Classroom & \multirow{7}{*}{$\begin{array}{l}\text { Personalization of the } \\
\text { learning proposal }\end{array}$} \\
\hline 1 & Discussion forums & $\mathrm{x}$ & $\mathrm{x}$ & $\mathrm{x}$ & \\
\hline 2 & File sharing & $\mathrm{x}$ & $\mathrm{x}$ & $\mathrm{x}$ & \\
\hline 3 & Internal mail & $\mathrm{x}$ & $\mathrm{x}$ & $\mathrm{x}$ & \\
\hline 4 & Diary / Notes Online & $\mathrm{x}$ & $\mathrm{x}$ & & \\
\hline 5 & Chat online & $\mathrm{x}$ & $\mathrm{x}$ & & \\
\hline 6 & Work progress calendar & $\mathrm{x}$ & & $\mathrm{x}$ & \\
\hline 7 & Authorization to courses & $\mathrm{x}$ & $\mathrm{x}$ & & \multirow{2}{*}{ User support } \\
\hline 8 & It has an installation manual & $\mathrm{x}$ & $\mathrm{x}$ & $\mathrm{x}$ & \\
\hline 9 & Workgroup & $\mathrm{x}$ & & $\mathrm{x}$ & \multirow{3}{*}{ Student Tools } \\
\hline 10 & Constant self-evaluation & $\mathrm{x}$ & $\mathrm{x}$ & & \\
\hline 11 & Briefcase & $\mathrm{x}$ & $\mathrm{x}$ & $\mathrm{x}$ & \\
\hline 12 & $\begin{array}{l}\text { Allows teachers to attach complementary academic } \\
\text { material }\end{array}$ & $\mathrm{x}$ & $\mathrm{x}$ & $\mathrm{x}$ & $\begin{array}{l}\text { Promotion of collaborative } \\
\text { learning }\end{array}$ \\
\hline
\end{tabular}

\section{RESULTS AND DISCUSSION}

\subsection{About the Case Study}

As a case study we have learning management platforms that are designed for a better understanding and easy development by the user, they are also used to comparing results between elements that make up web platforms. The analysis is performed by comparing the 3 learning management web platforms for a better understanding and easy use by the user, using agile techniques for each platform. Next, we will see the functionality of learning management systems.

\section{A. CHAMILO FUNCTIONALITY}

As for Chamilo we have the following description:

- Interaction: (photos, chats, file sharing, announcements, groups, tasks, wiki, users, surveys, personal notes, social networks, glossaries).

- Content: (lessons, managing a course, assessments, attendance, links, glossary, document management, thematic progress, exercises in the form of questions and time-controlled exams.

- Administration: (blog management, configuration and maintenance of courses, reports, documents) [12].

\section{B. MOODLE FUNCTIONALITY}

As for Moodle, you have the following:

- There are around 20 different activities, among them we have forums, glossaries, wikis, tasks, surveys, databases, among other things, and each one can be adapted to the needs of each course.

- Moodle allows combining the activities in sequences and groups, helping the teacher to guide the participants [13].

\section{GOOGLE CLASSROOM FUNCTIONALITY}

Next, the functionalities of Google Classroom are explained:

- Create and collect tasks (Google Docs, Drive and Gmail).

- Improve communication in class (announcements, questions and comments).

- Stay organized (Drive folders for each assignment and for each student) [14].

\subsection{About the Methodology}

As a methodology we have the architecture of the analytics of learning based on teachers and students using LMS. The learning analysis system is the customized one that users use for the algorithm and parameters. The LMS can also invoke the analysis customize interface to provide adaptive learning, function based on the analysis result[15]. As Figure 5 shows.

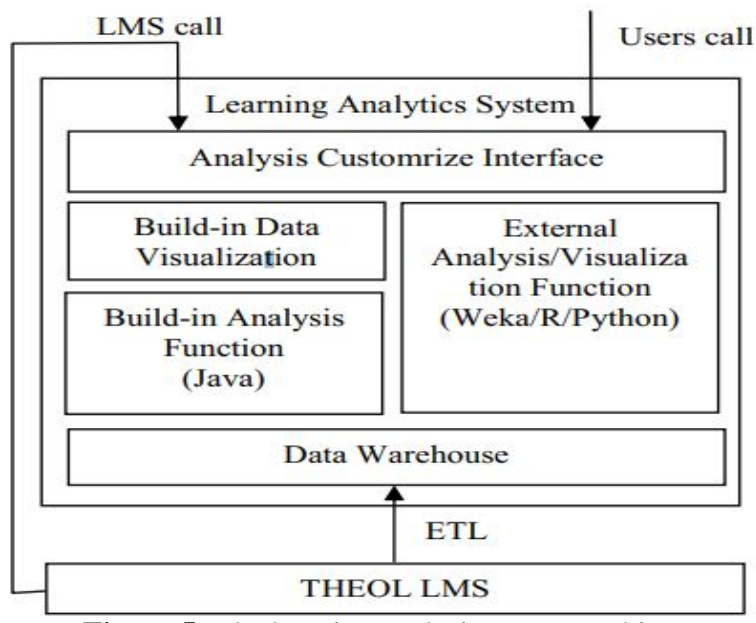

Figure 5: The learning analysis system architecture 
As another methodology we have the AHP hierarchical analytical process, based on the evaluation of teaching in universities, where it requires that the decision-maker provide subjective evaluations regarding the relative importance of each of the criteria and then specify their preference regarding each of the decision alternatives and for each criterion[16]. As shown in Figure 6.

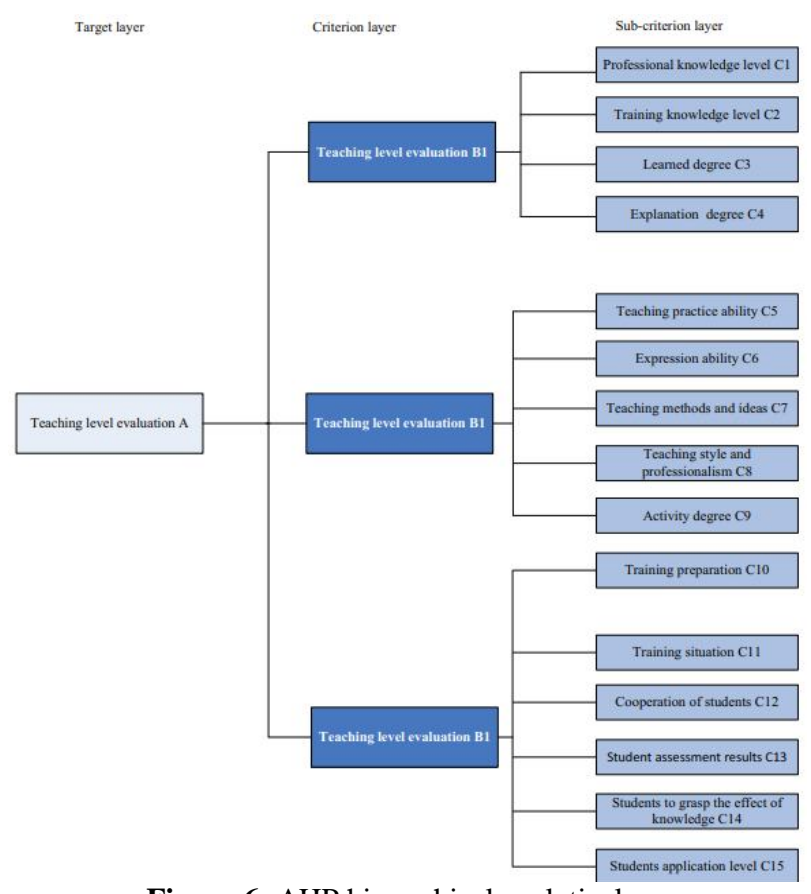

Figure 6: AHP hierarchical analytical process

\section{CONCLUSIONS}

In this article, we were able to analyze various learning management system platforms with the AHP tool, which shows the steps to be followed in order to carry out said analysis in the face of the social isolation produced by COVID, helping to achieve a better solution for schools and institutions. educational. Regarding the role of the student, they will have materials that allow them to develop their knowledge (such as audio, photo, chat, videos, etc.) and they will even be able to carry out the activities in the virtual classroom and do their homework, without the need to expose themselves.

The applied methodology was the most concrete, since it seeks to compare various platforms and characteristics, managing to use the AHP tool for the management of each web platform, giving a series of functionalities, benefits and requirements for its installation for the benefit of the student in the face of this tragedy, ensuring that development is not impaired in any case.

As future work it is desired to implement the various web platforms of learning management systems for the use of schools and institutes, taking into account their characteristics, functionalities and benefits at the time of implementation. Comparing the 3 platforms analyzed, Moodle ranks first worldwide and is the most used by more than $70 \%$ of users.

\section{REFERENCES}

[1] J. Ying, "Design and Implementation of Web-Based Enterprise Distance Education System," in 2010 International Forum on Information Technology and Applications, Jul. 2010, vol. 2, pp. 73-76, doi: 10.1109/IFITA.2010.116.

[2] Diseño e implementación del sistema de educación a distancia empresarial basado en la web. 2010 Foro Internacional de Tecnología de la Información y Aplicaciones|10.1109 / IFITA.2010.116." (accessed May 12, 2020).

[3] Moving teaching from blackboard to the learning management system - Helping absent students learn from home. 2018 41st International Convention on Information and Communication Technology, Electronics and Microelectronics (MIPRO) | 10.23919/MIPRO.2018.8400095."-(accessed Jun. 23, 2020).

[4] P. Carlos and A. O. Moreira, "Proyecto Final de Máster Modelo de selección y evaluación de plataformas LMS (Learning Management Systems) para docentes y proyectos educativos independientes."International Conference on Management

[5] J. Pang, L. Ma, and X. Liu, "The Performance Evaluation of ERP Systems Based on Fuzzy AHP," in 2010 International Conference on Management and Service Science, Aug. 2010, pp. 1-4, doi: 10.1109/ICMSS.2010.5576849.

[6] Modelos de evaluación para la plataforma de E-Learning: un enfoque AHP. Actas. Fronteras en la educación. 36 ${ }^{\mathrm{a}}$ Conferencia Anual | 10.1109 / FIE.2006.322312.” (accessed May 12, 2020).

[7] F. Colace, M. De Santo, and A. Pietrosanto, "Evaluation Models for E-Learning Platform: an AHP approach," in Proceedings. Frontiers in Education. 36th Annual Conference, Oct. 2006, pp. 1-6, doi: 10.1109/FIE.2006.322312.

[8] P. Poulova, B. Klimova, and M. Krizek, "Selected E-Learning Systems and Their Comparison," in 2019 International Symposium on Educational Technology (ISET), Jul. 2019, pp. 297-300, doi: 10.1109/ISET.2019.00070.

[9] J. S. Mtebe and A. W. Kondoro, "Using Mobile Moodle to enhance Moodle LMS accessibility and usage at the University of Dar es Salaam," in 2016 IST-Africa Week Conference, May 2016, pp. 1-11, doi: 10.1109/ISTAFRICA.2016.7530649.

[10] Fahrurrozi, U. Hasanah, and R. S. Dewi, "Integrated Learning Design Based on Google Classroom to Improve Student Digital Literacy," in 2019 5th International Conference on Education and Technology (ICET), Oct. 2019, pp. 108-111, doi: 10.1109/ICET48172.2019.8987219. 
[11] Elegir el LMS correcto: una evaluación de rendimiento de tres LMS de código abierto. 2013 IEEE Global Engineering Education Conference (EDUCON) | 10.1109 / EduCon.2013.6530119." (accessed Jun. 16, 2020).

[12] W. Liyong, Z. Chengling, L. Qingtang, and S. Junyi, "Work in progress-an evaluation model for learning content management systems: From a perspective of knowledge management," in Proceedings - Frontiers in Education Conference, FIE, 2005, vol. 2005, doi: 10.1109/fie.2005.1612111.

[13] L. Xiang-Feng, "Research on Information Course Design and Application Based on Moodle Platform," in 2014 7th International Conference on Intelligent Computation Technology and Automation, Oct. 2014, pp. 543-546, doi: 10.1109/ICICTA.2014.137.

[14] L. Alejandra, G. Maldonado, E. Alan, M. Domínguez, A. Laura, and P. Hinojosa, "EL USO DE GOOGLE CLASSROOM COMO APOYO PARA EL DOCENTE."

[15] Q. Zhou, X. Han, J. Yang, and J. Cheng, "Design and Implementation of Learning Analytics System for Teachers and Learners Based on the Specified LMS," in 2014 International Conference of Educational Innovation through Technology, Oct. 2014, pp. 79-82, doi: 10.1109/EITT.2014.21.

[16] X. An, "Teaching Level Evaluation Approach Based on AHP for Yoga Training in Colleges," in 2016 International Conference on Smart City and Systems Engineering (ICSCSE), Nov. 2016, pp. 406-410, doi: 10.1109/ICSCSE.2016.0113. 